\title{
Performance and Profitability of Rain-Based Thresholds for Timing Fungicide Applications in Soybean Rust Control
}

\author{
Gustavo C. Beruski, ${ }^{1}$ Emerson M. Del Ponte, ${ }^{2}$ André. B. Pereira, ${ }^{3}$ Mark L. Gleason, ${ }^{4}$ Gil M. S. Câmara, ${ }^{5}$ Ivan P. Araújo Junior, ${ }^{6}$ \\ and Paulo C. Sentelhas ${ }^{1, \dagger}$ \\ ${ }^{1}$ Departamento de Engenharia de Biossistemas, ESALQ - Universidade de São Paulo, Piracicaba, São Paulo State, 13418-900, \\ Brazil \\ ${ }^{2}$ Departamento de Fitopatologia, Universidade Federal de Viçosa, Viçosa, Minas Gerais State, 36570-000, Brazil \\ ${ }^{3}$ Departamento de Ciências do Solo e Engenharia Agrícola, Universidade Estadual de Ponta, Ponta Grossa, Paraná State, 84010- \\ 330, Brazil \\ ${ }^{4}$ Department of Plant Pathology and Microbiology, Iowa State University, Ames, IA 50011-1101, U.S.A. \\ ${ }^{5}$ Departamento de Produção Vegetal, ESALQ - Universidade de São Paulo, Piracicaba, São Paulo State, 13418-900, Brazil \\ ${ }^{6}$ Departamento de Fitopatologia, Fundação Mato Grosso, Rondonópolis, Mato Grosso State, 78750-000, Brazil
}

\begin{abstract}
Soybean rust (SBR), caused by the fungus Phakopsora pachyrhizi, is the most damaging disease of soybean in Brazil. Effective management is achieved by means of calendar-timed sprays of fungicide mixtures, which do not explicitly consider weather-associated disease risk. Two rain-based action thresholds of disease severity values (DSV50 and DSV80) were proposed and compared with two leaf wetness duration-temperature thresholds of daily values of infection probability (DVIP6 and DVIP9) and with a calendar program, with regard to performance and profitability. An unsprayed check treatment plot was included for calculating relative control. Disease severity and yield data

conditions. The less conservative rainfall action threshold (DSV80) resulted in fewer fungicide sprays compared with the other treatments, and the more conservative one (DSV50) resulted in fewer sprays than the DVIP thresholds. Yield was generally higher with the increase in spray number, but the economic analysis showed no significant differences in the risk of not offsetting the costs of fungicide sprays regardless of the system. Therefore, based on the simplicity and the profitability of the rain-based model, the system is a good candidate for incorporating into the management of SBR in soybean production fields in Brazil.
\end{abstract} were obtained from 29 experiments conducted at six sites across four states in Brazil during the 2012-13, 2014-15, and 2015-16 growing seasons, which represented different growing regions and climatic
Keywords: Phakopsora pachyrhizi, Glycine max, disease warning system
Soybean rust (SBR), caused by Phakopsora pachyrhizi, is the most destructive disease of soybean (Godoy et al. 2016; Hartman et al. 2016). In Brazil, the fungus thrives in most of the soybeangrowing regions of the country, where it can overwinter in volunteer plants, build up its population early in the season, disperse easily via air currents, and cause epidemics on commercial crops every season (Dalla Lana et al. 2018; Del Ponte et al. 2006a; Godoy et al. 2016). Moisture and temperature-related variables, including rainfall, leaf wetness duration, air relative humidity and temperature, solar radiation, and wind speed, influence all phases of the SBR life cycle (Del Ponte and Esker 2008). Several of these weather variables have been included as predictors in mathematical models developed for risk assessment and analysis or to be incorporated into disease warning systems (DWSs) (Del Ponte et al. 2006b).

${ }^{\dagger}$ Corresponding author: P. C. Sentelhas; pcsentel.esalq@usp.br

G. C. Beruski and E. M. Del Ponte contributed equally to the current study.

Funding: G. C. Beruski thanks CNPq and Fundação de Amparo à Pesquisa do Estado de São Paulo (FAPESP)-CAPES for the financial support through the Ph.D. scholarship (process no. 2014/05677-1 and no. 2016/06764-0).

*The $\boldsymbol{e}$-Xtra logo stands for "electronic extra" and indicates that one supplementary table is published online.

The author(s) declare no conflict of interest.

Accepted for publication 2 April 2020.

(C) 2020 The American Phytopathological Society
A DWS is a management aid tool that provides disease risk information during the growing season in order to inform growers' decisions such as timing of fungicide applications (Gent et al. 2013). The core of a DWS is an algorithm or model (mathematical equation or rule) that requires at least one estimated/measured predictor (Magarey and Isard 2017; Magarey and Sutton 2007; Shtienberg 2000). Most models used in DWSs are derived from experimental data collected in field or controlled environments and should ideally be evaluated under a broad range of natural conditions before being recommended operationally (Rossi et al. 2010). Although disease risk predictors can be related to host, inoculum, or agronomic factors, most DWSs are usually based on a few key weather-related variables, especially when targeting conditions that lead to infection or disease progress (Magarey and Isard 2017; Shtienberg 2000).

In theory, a DWS can lead to a reduction in the number of sprays when compared with calendar systems whenever the environment is less disease-conducive while also providing commercially acceptable suppression of targeted diseases. Thereby, a DWS maximizes benefit-cost ratio and mitigates environmental and other indirect impacts due to the indiscriminate use of fungicides (Abuley and Nielsen 2017; Gleason et al. 1995; Rosli et al. 2017). Conversely, many calendar systems have rules of thumb that account for critical stages of crop phenology/growth for timing the first spray as well as length of the residual period of fungicides for defining spray intervals. These systems are suitable for situations in which disease risk is generally high and the first fungicide applications cannot be delayed (Shtienberg 2000). According to Scherm et al. (2009), fungicide applications for SBR control that are made during the presymptomatic stage often lead to enhanced protection and increased response in yield. Therefore, calendar systems are very convenient and may be cost-effective, but there is a downside: when applied sequentially and excessively, fungicides with single sites of action against 
pathogen metabolism boost selection for resistance to the active ingredients in the pathogen population, a situation that has been increased in Brazil recently (Godoy 2011; Godoy et al. 2016). This is already occurring in Brazil for SBR after more than a decade of fungicide use, and significant declines in efficacy have been reported for several sole or premix commercial fungicide ingredients (Dalla Lana et al. 2018) with different modes of actions.

Although weather conditions that favor SBR have been identified and over a dozen models developed for this disease, with a few suitable to integrate into warning systems (Del Ponte et al. 2006b), the rate of adoption of a DWS for this disease in Brazil has been low. Uncertainty about logistical factors such as the availability, reliability, and profitability, as well as questions about their long-term sustainability, are common barriers limiting the broader adoption of a DWS (Gent et al. 2013).

The scientific evaluation of the performance and value of warning systems for SBR are scarce compared with research aimed at model development (Del Ponte et al. 2006b; Megeto et al. 2014; Minchio et al. 2016; Tao et al. 2009). Very few studies evaluated warning systems based on rainfall and the leaf wetness duration-temperature (LWD-T) interaction targeting SBR control (Igarashi et al. 2016; Kelly et al. 2015), which may be limited by the lack of validated systems. In fact, most of the SBR epidemiological models were originally developed for risk assessment and scenario analysis (Del Ponte et al. 2006b, 2011; Tao et al. 2009). To the best of our knowledge, there is only one type of infection-based model adapted to function as an SBR rust warning (Magarey and Sutton 2007). This one considers the interaction effect between leaf wetness and air temperature during an uninterrupted wet period within a 24-h period (Reis et al. 2004). Using data from Melching et al. (1989), Reis et al. (2004) developed a table of daily values of infection probability (DVIP), which has been adapted to predict and map SBR risk in Brazil (Del Ponte et al. 2006b; Igarashi et al. 2016). Another use of an infection-based type of model was proposed and used in a risk assessment study in the United States to map favorable areas for disease establishment (Magarey et al. 2007). We are aware of only one study that compared rainfall and/or LWD-T models, and two that evaluated rainfall models, with regards to the performance to predict disease risk, but they were limited to only a few epidemics in a single location (Kelly et al. 2015; Igarashi et al. 2016; Nunes et al. 2018). Although appealing, several difficulties to continuing operational use of leaf wetness as predictor in those systems have been highlighted (Rowlandson et al. 2015), so that relatively simpler systems that use rain or relative humidity as predictors have been proposed as alternatives.

The main objective of the current study was to develop and evaluate a simple DWS in Brazil based on summaries of daily rainfall for recommending fungicide sprays against SBR. The new warning system was compared with another system based on the LWD-T model and a standard calendar spray program with regard to performance and profitability in the tropical weather conditions of Brazil.

\section{Materials and Methods}

Rain-based warning system. Del Ponte et al. (2006b) fitted multiple linear regression models of end-of-season severity of SBR in field experiments all over Brazil. The best model (BR1) used number of rainy days and cumulative rainfall recorded during a 30-day period over the course of epidemics. We adapted the BR1 model to run in a 30-day moving window and produce a daily output, defined as a daily severity value (DSV). Contrary to methods used in the original study, DSV was obtained from modifying the equation to calculate two partial DSV (PDSV) values using rainfall amount and frequency within each of two sequential periods (A or B) of 15 days prior to risk calculation, which was given by the following equation:

$$
\mathrm{PDSV}_{n}=-2.1433+0.3622 \times \text { RainAcc }+2.573 \times \text { RainNOD }
$$

where $n$ corresponds to the 30-day period prior to the date of PDSV calculation (A from days 1 to 15 and B from days 16 to 30 before calculation), RainAcc is the cumulative sum of rainfall $(>0.5 \mathrm{~mm})$ for each period (A or B), and RainNOD is the number of rainy days within the same periods. The DSV was obtained by summing PDSVs for $\mathrm{A}$ and $\mathrm{B}$. The $\mathrm{A}$ and $\mathrm{B}$ periods are assigned different weights, with the most recent period $(\mathrm{A})$ assigned a higher weight $(0.7)$ than period $\mathrm{B}(0.3)$. The DSV was then given by the following equation:

$$
\mathrm{DSV}=\mathrm{PDSV}_{A} \times 0.7+\operatorname{PDSV}_{B} \times 0.3
$$

The 3-day moving average of daily calculated DSV was used as a critical value for an action threshold (AT). Two ATs, named DSV50 and DSV80, were defined to trigger fungicide sprays. The DSV50 is more conservative, or when the end user is less tolerant to risk (spray more). The DSV80 is less conservative, or when the end user is more risk tolerant (spray less). The values of the two ATs were not fixed but were linearly reduced for each subsequent spray (Table 1). This reduction was used to account for the increase in amount of secondary inoculum, given that the efficacy of the sprays is not complete. The spray is applied at the respective AT, and no sprays are made during a fungicide efficacy residual period (defined here as 14 days). The DSV was calculated continuously after the residual period had elapsed; whenever a sum of DSVs reached the AT (Table 1), a fungicide spray was warned and applied.

LWD-T warning system. A risk-point table was proposed by Reis et al. (2004) using data from controlled environment experiments conducted in the Foreign Disease-Weed Science Research Laboratory that is linked to the USDA Agricultural Research Service (Melching et al. 1989) to determine the interaction effect of the leaf wetness duration (LWD) and air temperature $\left(\mathrm{T}_{\mathrm{LWD}}\right)$ during $\mathrm{LWD}$

Table 1. Threshold values for a daily disease severity value (DSV, in \%) calculated by a prediction model that uses amount and frequency of rainfall events during the previous 30-day period ${ }^{\mathrm{z}}$

\begin{tabular}{lcccc}
\hline & \multicolumn{4}{c}{ Position of the spray in the sequence } \\
\cline { 2 - 5 } Action threshold & 1st & 2nd & 3rd & 24th \\
\hline DSV80 & 80 & 60 & 55 & 50 \\
DSV50 & 50 & 45 & 35 & 30 \\
\hline
\end{tabular}

$\mathrm{z}$ When the threshold is reached during a day when a spray was planned, the spray is made; otherwise, the spray is on hold until the threshold is reached. The threshold decreases for following sprays due to inoculum buildup from secondary infections and host susceptibility at the later stages.

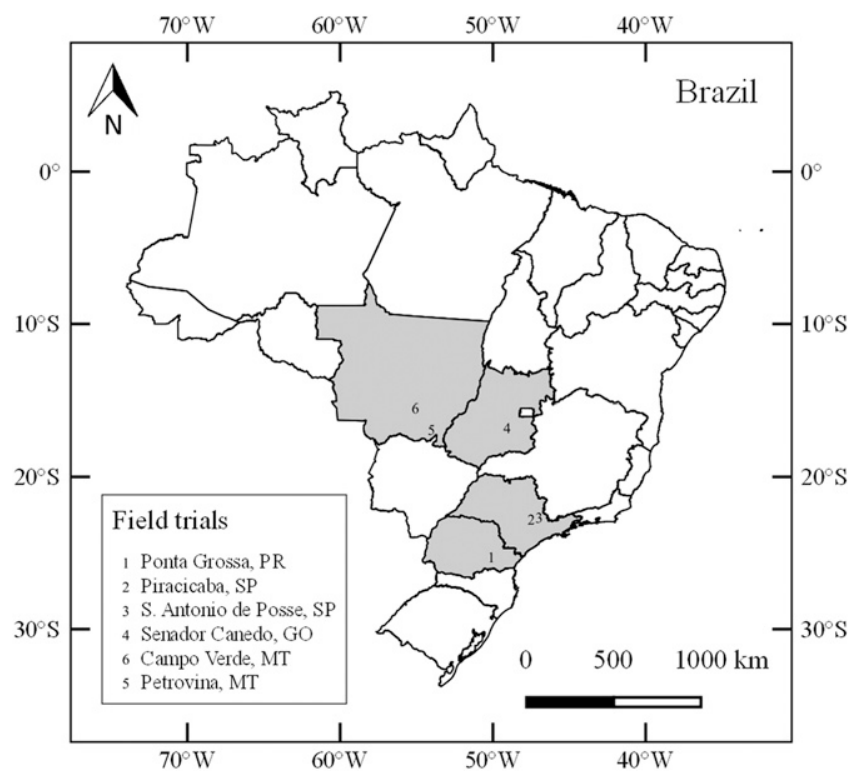

Fig. 1. Soybean field trial locations where soybean rust was assessed along with automatic weather stations to collect meteorological data for running the disease warning systems. 
periods. The surface response model that predicts the number of lesions $/ \mathrm{cm}^{2}$ of SBR is given by Reis et al. (2004):

$$
\begin{aligned}
\mathrm{NL}=12.611 & \times \operatorname{Exp}\left\{-5 \times\left[\left(\frac{\mathrm{LWD}-21.41}{4.22}\right)^{2}\right.\right. \\
& \left.\left.+\left(\frac{\mathrm{T}_{\mathrm{LWD}}-14.14}{2.43}\right)^{2}\right]\right\}
\end{aligned}
$$

where LWD is the leaf wetness duration from 12:01 on the first day until 12:00 of the next day and $\mathrm{T}_{\mathrm{LWD}}$ is the average air temperature during the LWD. The NL values were categorized into four classes to define a daily value of infection probability (DVIP) as follows: 0 $\left(\mathrm{NL}=0\right.$ lesions $\left./ \mathrm{cm}^{2}\right), 1\left(\mathrm{NL}=0.1\right.$ to 3.0 lesions $\left./ \mathrm{cm}^{2}\right), 2(\mathrm{NL}=3.1$ to 6 lesions $/ \mathrm{cm}^{2}$ ), and $3\left(\mathrm{NL}=6.1\right.$ to 9 lesions $\left./ \mathrm{cm}^{2}\right)$ (Supplementary Table S1). Two ATs were defined, based on the sum of DVIP (AT $=6$ for the more conservative threshold, and AT $=9$ for the less conservative threshold) during a 7-day period, which was assumed to be the mean latent period for SBR (Marchetti et al. 1976).

Calendar system. The calendar system was defined based on current and widespread practices adopted for SBR control in Brazil. The first spray was recommended whenever plants approached flowering or during canopy closure, and the following sprays were applied on an approximately 14-day interval until the plants approached the maturity phenological R7 stage (Fehr and Caviness 1977; Godoy et al. 2016).

Field trials. A total of 29 experiments were conducted at six specific sites located in four Brazilian states (Paraná, São Paulo, Goiás, and Mato Grosso State). These locations are representative of subtropical and tropical climates (Fig. 1; Table 2). Two sets of experiments were combined for analysis. The first set of five experiments was conducted in 2013 at the BASF experimental stations in Senador Canedo, GO; Santo Antônio de Posse, SP; and Ponta Grossa, PR. These trials were sown relatively late in the growing season (which extends from December to April) to ensure SBR inoculum availability. The fungicide used was Opera (BASF, Ludwigshafen, Germany), a commercial mixture of pyraclostrobin (quinone outside inhibitor [QoI]) + epoxiconazole (demethylation inhibitor) at a rate of 0.5 liter/ha. The second set of experiments was composed of 24 field trials, which was carried out throughout the 2015 and 2016 harvest seasons in Ponta Grossa, PR; Pedra Preta, MT; Piracicaba, SP; and Campo Verde, MT. In that set, the experiments were sowed sequentially in the same season, spaced about a month apart, from October to February (Table 2); furthermore, the fungicide used to control SBR was a commercial mixture (Elatus, Syngenta, Basel, Switzerland) containing azoxystrobin (QoI) + benzovindiflupyr (succinate dehydrogenase inhibitor) at a rate of 150 $\mathrm{g} / \mathrm{ha}$.

Soybeans were seeded at $0.45-\mathrm{m}$ row spacing for all experiments, except for Senador Canedo, where $0.5 \mathrm{~m}$ was used. The plant population ranged from 12 to 16 plants per meter of row due to distinct growing habits and maturation group among cultivars. Before sowing, $100 \mathrm{~kg}$ of soybean seeds was treated with $200 \mathrm{ml}$ of a commercial mixture (Standak Top, BASF) of fungicide (pyraclostrobin and thiophanate-methyl) and insecticide (fipronil). Seeds were further inoculated with nitrogen-fixing bacteria (Bradyrhizobium japonicum inoculum lineages SEMIA 5079 and 5080) at a concentration of $5 \times 10^{9} \mathrm{CFU} / \mathrm{ml}$

Treatments and experimental design. There were four DWS treatments to indicate fungicide spray timing, two defined based on

Table 2. Information for the sites and experiments conducted in Brazil for evaluating the performance of soybean growing season, cultivar sowed, and sowing

\begin{tabular}{|c|c|c|c|c|c|}
\hline Site name and geolocation & Elevation (m) & Köppen climate ${ }^{y}$ & Harvest season & Sowing date & Cultivar ${ }^{\mathrm{z}}$ \\
\hline \multirow{2}{*}{$\begin{array}{l}\text { Senador Canedo } \\
16^{\circ} 44^{\prime} \mathrm{S} ; 49^{\circ} 59^{\prime} \mathrm{W}\end{array}$} & \multirow[t]{2}{*}{737} & \multirow[t]{2}{*}{ Aw } & 2013 & $20 \mathrm{Jan}$ & BRS Valiosa RR \\
\hline & & & 2013 & $20 \mathrm{Feb}$ & BRS Valiosa RR \\
\hline \multirow{2}{*}{$\begin{array}{l}\text { S. Antônio de Posse } \\
22^{\circ} 35^{\prime} \mathrm{S} ; 46^{\circ} 59^{\prime} \mathrm{W}\end{array}$} & \multirow[t]{2}{*}{755} & \multirow[t]{2}{*}{ Cwa } & 2013 & $11 \mathrm{Dec}$ & Coodetec $236 \mathrm{RR}$ \\
\hline & & & 2013 & $31 \mathrm{Jan}$ & Coodetec $236 \mathrm{RR}$ \\
\hline \multirow{9}{*}{$\begin{array}{l}\text { Piracicaba } \\
222^{\circ} 42^{\prime} \mathrm{S} ; 47^{\circ} 30^{\prime} \mathrm{W}\end{array}$} & \multirow[t]{9}{*}{546} & \multirow[t]{9}{*}{ Cwa } & 2015 & 23 Oct & BMX Potência RR \\
\hline & & & 2015 & $18 \mathrm{Nov}$ & BMX Potência RR \\
\hline & & & 2015 & $12 \mathrm{Dec}$ & BMX Potência RR \\
\hline & & & 2015 & $20 \mathrm{Jan}$ & BMX Potência RR \\
\hline & & & 2015 & $19 \mathrm{Feb}$ & BMX Potência RR \\
\hline & & & 2016 & 22 Oct & Monsoy 6410 IPRO \\
\hline & & & 2016 & $19 \mathrm{Nov}$ & Monsoy 6410 IPRO \\
\hline & & & 2016 & $18 \mathrm{Dec}$ & Monsoy 6410 IPRO \\
\hline & & & 2016 & $20 \mathrm{Jan}$ & Monsoy 6410 IPRO \\
\hline \multirow{8}{*}{$\begin{array}{l}\text { Ponta Grossa } \\
225^{\circ} 05^{\prime} \mathrm{S} ; 50^{\circ} 09^{\prime} \mathrm{W}\end{array}$} & \multirow[t]{8}{*}{969} & \multirow[t]{8}{*}{$\mathrm{Cfb}$} & 2012 & $12 \mathrm{Apr}$ & BMX Potência RR \\
\hline & & & 2015 & 16 Oct & BMX Potência RR \\
\hline & & & 2015 & $11 \mathrm{Nov}$ & BMX Potência RR \\
\hline & & & 2015 & $18 \mathrm{Dec}$ & BMX Potência RR \\
\hline & & & 2015 & 15 Jan & BMX Potência RR \\
\hline & & & 2016 & $21 \mathrm{Nov}$ & Monsoy 6410 IPRO \\
\hline & & & 2016 & $11 \mathrm{Dec}$ & Monsoy 6410 IPRO \\
\hline & & & 2016 & $23 \mathrm{Jan}$ & Monsoy 6410 IPRO \\
\hline \multirow{7}{*}{$\begin{array}{l}\text { Campo Verde } \\
15^{\circ} 23^{\prime} \mathrm{S} ; 55^{\circ} 03^{\prime} \mathrm{W}\end{array}$} & \multirow[t]{7}{*}{667} & \multirow[t]{7}{*}{$\mathrm{Aw}$} & 2015 & $21 \mathrm{Oct}$ & TMG 132 RR \\
\hline & & & 2015 & $13 \mathrm{Nov}$ & TMG 132 RR \\
\hline & & & 2015 & $12 \mathrm{Dec}$ & TMG 132 RR \\
\hline & & & 2016 & $23 \mathrm{Oct}$ & TMG 132 RR \\
\hline & & & 2016 & $7 \mathrm{Nov}$ & TMG $132 \mathrm{RR}$ \\
\hline & & & 2016 & $9 \mathrm{Dec}$ & TMG 132 RR \\
\hline & & & 2015 & $21 \mathrm{Oct}$ & TMG 132 RR \\
\hline \multirow{2}{*}{$\begin{array}{l}\text { Pedra Preta } \\
\quad 16^{\circ} 51^{\prime} \mathrm{S} ; 54^{\circ} 01^{\prime} \mathrm{W}\end{array}$} & \multirow[t]{2}{*}{745} & \multirow[t]{2}{*}{ Aw } & 2016 & $6 \mathrm{Nov}$ & TMG $132 \mathrm{RR}$ \\
\hline & & & 2016 & $3 \mathrm{Dec}$ & TMG 132 RR \\
\hline
\end{tabular}
dates, in field trials to assess the performance of different methodology for soybean rust in Brazil

y Köppen climate classification over the field trials: $\mathrm{Aw}=$ tropical with a dry winter; $\mathrm{Cwa}=$ humid subtropical, with a dry winter and hot summer; and $\mathrm{Cfb}=$ humid subtropical, without a dry season and temperate summer (Alvares et al. 2013).

${ }^{\mathrm{z}}$ Main cultivar characteristics: BRS Valiosa $\mathrm{RR}=$ determinate growth, and maturity group 8.1 ; Coodetec $236 \mathrm{RR}=$ determinate growth, and maturity group 6.2 ; BMX Potência RR = indeterminate growth and maturity group 6.7; Monsoy 6410 IPRO = indeterminate growth, and maturity group 6.4; and TMG 132 RR = determinate growth, and maturity group of 8.5 . All genetic materials are susceptible to soybean rust. 
a rainfall-based warning system that used two different action thresholds (DSV80 and DSV50) and two based on an LWD-T system (DVIP $=6$ and DVIP $=9$ ). A nonspray (untreated) check and calendar-based fungicide spray program were included in all experiments (Table 1). The LWD-T systems were not evaluated in the four 2013 BASF trials. Each plot was composed of five sowing rows with 4 m length, except in Campo Verde and Pedra Preta, where the plots were $7 \mathrm{~m}$ in length. The experiment was conducted in a randomized complete block design with four replicates in all trials. Fungicides were applied with a $\mathrm{CO}_{2}$-pressurized backpack sprayer with a spray boom (TEEJET XR/11002, VP) on which four nozzles were spaced $0.45 \mathrm{~m}$ apart. Sprayer pressure was 200 to $250 \mathrm{kPa}$, with applications performed at a speed of $4.5 \mathrm{~km} / \mathrm{h}$ to apply approximately 200 liters/ha.

Weather monitoring. Meteorological data were monitored using automatic weather stations installed in standard conditions (mowed turfgrass or over the soybean crop) located at approximately $10 \mathrm{~m}$ away from the edge of each trial plot. Electronic sensors measured air temperature and relative humidity (Model HMP35C, Vaisala, Helsinki, Finland), LWD (cylindrical sensors, Weather Innovation, Chatham, Canada), and rainfall (Model TR-565M, Texas Electronics, Dallas, TX). Data were recorded by dataloggers (Models CR10, CR10X, and CR1000, Campbell Scientific, Logan, UT) each minute, and averages were calculated every $15 \mathrm{~min}$. The data were downloaded daily in the morning in order to calculate DWS outputs and allow sprays to occur on the same day or, if not possible, at the beginning of the next day.

Disease and yield assessments. Assessments of SBR severity were made in three central rows of each plot. Four arbitrarily selected leaflets at each canopy height (lower, middle, and upper) were assessed individually, using a standard area diagram as a reference (Godoy et al. 2006), and averaged to obtain a mean plot value (Scherm et al. 2009). Except for the experiments carried out in Mato Grosso state, the assessments were made every 7 or 15 days beginning shortly after the first symptoms became visible until the beginning of maturation of the soybean crop. In the experiments conducted in Campo Verde and Pedra Preta, canopy defoliation was determined visually at the beginning of maturity (R7), represented by one pod on the main stem with mature color (Fehr and Caviness 1977) based on a diagrammatic scale proposed by Hirano et al. (2010).

Soybeans were harvested at physiological maturity stage. An area of $5.4 \mathrm{~m}^{2}$ per plot was harvested in all trials, excepting in Senador Canedo, where the area was $4 \mathrm{~m}^{2}$. For each plot, the three central rows, excluding $1.0 \mathrm{~m}$ at each end, were harvested to determine yield and mass per thousand seeds. For both yield variables, data were determined at $13 \%$ grain moisture content.

Exploratory analysis and treatment efficiency. Exploratory analysis (boxplots) was used to depict final (end-of-season) SBR severity and yield conditioned to each treatment. We focused the analysis on end-of-season severity because area under the disease progress curve was available in only 16 trials, and the number of assessments was generally low (three to five). The number of fungicide sprays per site-year was summarized as both median and mean values for each treatment in all trials.

The means of control efficacy or percent control $(\% C)$ describe the disease reduction in relation to the untreated check, and the number of fungicide sprays per site-year were used to calculate fungicide use efficiency $(E)$, similar to Small et al. (2015), which is simply given by $\% C$ divided by the number of scheduled sprays. For example, if more sprays are needed for treatment A to reduce disease to the same level as treatment B, the use of treatment A is less efficient. $E$ was summarized at both the individual trial level and combined across all trials.

Effect of treatments on disease control and yield response. A mixed modeling approach was used to summarize disease control $(\% C)$ and yield response given by the absolute difference $(D)$ between yield in the treated areas subtracted from yield in the untreated check across trials. For disease control, the model was fitted directly to the $\log$ of the means. The percent control $(\% C)$ was further obtained by taking the difference between the two estimated logs of means (treated and untreated), which equals the ratio of the two means (Paul et al. 2008). The mean and 95\% confidence interval (CI) of the ratios were back-transformed to obtain percent control as described elsewhere (Machado et al. 2017; Paul et al. 2010).

For summarizing the yield response to the treatments, no transformation or standardization was required; the absolute difference in yield was calculated directly after model fitting by subtracting estimated means for the treatments under comparison (fungicidetreated minus untreated) (Machado et al. 2017). For both variables, field trials were considered as random effects in the model. Maximum likelihood estimation models were fitted to the data using the lmer function of the lme4 $\mathrm{R}$ package (Bates et al. 2015).

Economic analysis. An economic analysis was performed to calculate the probability of loss (Ploss), or the risk of not offsetting the costs of fungicide sprays (fungicide + application), recommended by each system. All costs associated with using the warning systems were computed in this analysis. The probability was given by $\phi\left\{\bar{D}-\left[\left(T_{\mathrm{C}} \times N_{\mathrm{S}}\right) / S_{\mathrm{P}}\right] / \sqrt{\hat{\tau}}\right\}$, where $\varphi$ is the cumulative standardnormal function (Machado et al. 2017; Paul et al. 2010); $\bar{D}$ and $\hat{\tau}$ are the means and variance, respectively, of the difference in yield between the treatment and the untreated check; $T_{\mathrm{C}}$ is the fungicide treatment cost; $N S$ is the number of sprays recommended by a warning system; and $S_{\mathrm{P}}$ is the soybean price. For the purpose of comparison

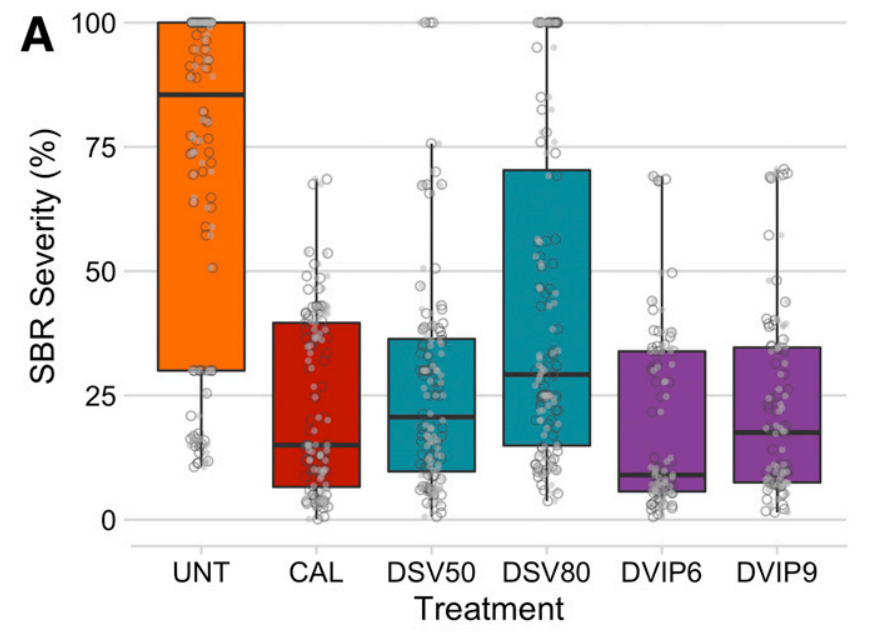

B

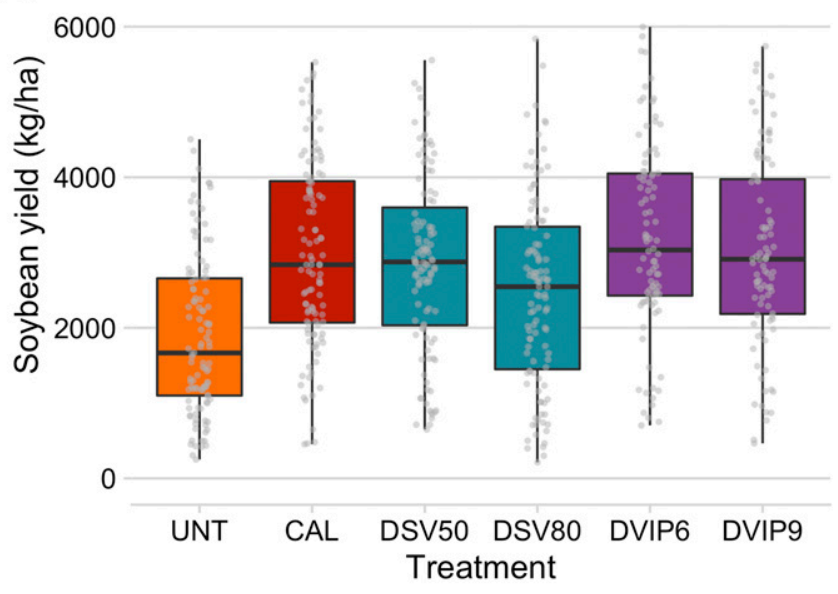

System 审 None Growth stage 审 Rainfall

Fig. 2. Boxplots for the distribution of maximal (end-of-season) A, soybean rust severity and $\mathbf{B}$, crop yield responses conditioned to a calendarized (CAL) system or two warning system-based thresholds defined based on rain (DSVs) or the interaction of leaf wetness duration and temperature (DVIPs). Disease severity (21 trials) and yield (29 trials) were measured at replicated field trial experiments conducted at six Brazilian locations in 2013, 2015, and 2016. UNT = untreated. 
and simplification, the price was defined for each of the two fungicide mixtures as US $\$ 25 /$ ha (BRL $\$ 71.25$ ). The operational costs were fixed at US\$10/ha, and the average soybean price used was US\$440/t. The distribution of the Ploss values across trials was depicted using bar plots, and the overall means and respective 95\% CI of Ploss values for each treatment were estimated using the same linear mixed model fitted to estimate fungicide efficacy and yield response.

Data processing and analysis. All data processing and analyses, as well as graphical work, were performed with $\mathrm{R}$ version 3.5.1 (2019-09-13). Several R packages of the tidyverse (Wickham et al. 2019) were used to prepare, transform, and visualize the data. The R scripts with text annotations were prepared as R Markdown documents (Xie et al. 2018), and all files were organized as a research compendium (Gentleman and Temple Lang 2007) structured as an RStudio project (Gandrud 2016). To encourage and facilitate reproducibility, a website was generated to navigate through the documented code. All files are publicly available at https://osf.io/ahnyj.

\section{Results}

Disease pressure and baseline yield. There was a considerable variation in disease pressure, expressed by SBR severity in the untreated plots, across the environments (sites $\times$ years $\times$ planting dates). Mean severity in those plots ranged from 11.2 to $100 \%$, averaging $69.8 \%$ across the set of 21 trials where this variable was obtained (Fig. 2A). Severity was not obtained in Campo Verde and Pedra Preta, where only percent defoliation due to SBR was measured.

The mean severity in the untreated plots was lower in Senador Canedo (30\%, $n=2$ trials), of intermediate level in Ponta Grossa $(47.2 \%, n=8)$, and higher in Piracicaba $(92.1 \%, n=9)$ and $\mathrm{S}$. Antônio de Posse $(100 \%, n=2)$ (data not shown). For the two sites where more than two sequential sowing dates were evaluated in the same season, severity was consistently higher at Piracicaba (65.9 to $100 \%$ ). It was more variable in Ponta Grossa, being higher in 2015 (18 to $81 \%$ ) than in 2016 (11.5 to $16 \%)$. The overall baseline yield in the untreated plots across all trials averaged $1,879 \mathrm{~kg} / \mathrm{ha}$ (250 to $4,504 \mathrm{~kg} / \mathrm{ha}$ ) (Fig. 2B). For the three sites with sequential sowings throughout the same growing season, there was a trend of decreasing baseline yield with delay of sowing date.

Effect of treatments on SBR severity and crop yield. As expected, the application of fungicides, regardless of the fungicidespray timing systems, consistently reduced mean final SBR severity compared with the untreated check (Fig. 2A). The median values across the calendar system and the two DWSs were mostly $<30 \%$. The median and range in SBR severity (0 to $70 \%)$ were generally similar in most of the systems, with the exception of the less conservative rainfall-based threshold (DSV80), for which there were more occurrences of severity $>70 \%$ (Fig. 2A). Median yield was also similar among fungicide-treated plots, approximating $3,000 \mathrm{~kg} / \mathrm{ha}$ among the four warning-system treatments and the calendar-based system (Fig. 2B).
Meta-analytic estimates of control and yield response. The estimates of mean SBR control ranged from 46 to $82.7 \%$ across the treatments (Table 3). An apparent higher percent control $(82.7 \%)$ was obtained using the more conservative threshold of the LWDT system (DVIP6), but it was statistically similar to calendarbased spray timing $(74.2 \%)$ and the less conservative threshold of the same system $(75.7 \%)$. Means of the more conservative rainfall-based action threshold (DSV50 $=68.6 \%$ ) did not differ statistically from either the calendar approach or the DVIP9 treatment. The lowest mean control efficacy $(46 \%)$ was achieved using the less conservative action threshold of the rainfall-based system $($ DSV80 $=46 \%)($ Table 3$)$. Values of fungicide use efficiency $(E)$ were two to three times more efficient in the rain-based systems (fewer sprays) than the LWD-T systems and the calendar system (Table 3). Yield generally increased with more sprays and percent control considering all treatments. The highest soybean yield was that obtained using the DVIP6 warning system, which differed from others $(P<0.01)$. Soybean yield in plots treated following the DVIP9, calendar, and DSV50 systems did not differ among them, ranging between 1,128 and $975 \mathrm{~kg} / \mathrm{ha}$. As expected, soybean yield obtained in the less conservative rainfall-based warning system (DSV80) was the lowest among fungicide-sprayed treatments (537 kg/ha) (Table 3).

Number of sprays and between-spray intervals. Variation in the mean level of SBR control was associated with the number of sprays. For example, in the more conservative LWD-T system that led to the highest level of disease control, the mean number of sprays was 4.7, whereas in the calendar-based and the other fungicide-spray systems, except for DSV50, one spray was saved, on average (Fig. 3A). The two action thresholds of the LWD-T system and the calendar schedule were the only ones to advise application of a sixth spray in a given season (Fig. 3A). The two rainfall-based systems were more variable in the number of sprays, ranging from zero (DSV80) to four sprays (DSV50). An additional source of variation in the number of sprays may have been differences in the time from issuance of a spray advisory and application of the spray, because the earlier the sprays were initiated, the longer the remaining window of time for further applications (Fig. 3B). The LWD-T systems recommended the first spray approximately 10 days earlier than the calendar-based system and more conservative rainfall-based system (DSV50), which were similar to each other (Fig. 3B).

The overall means of between-spray interval were shortest for the calendar system (15.7 days) followed by DVIP6, DSV50, DVIP9, and DSV80, with intervals of 17.1, 17.4, 19.2, and 22.8 days, respectively (Fig. 3C). There were no marked differences among the median number of days between a pair or sequential sprays, but the largest among-trial variation for the same spray sequence (notably first and second and second and third) occurred for the LWD-T system.

Profitability analysis. Values of the difference in yield for the fungicide treatments, regardless of the system, compared with nontreated plots were mostly positive (yield higher in the fungicide-sprayed

Table 3. Meta-analytic estimates of control efficacy and yield response, number of sprays, and fungicide use efficiency $(E)$ for three different decision support systems based on calendarized applications (CAL); rainfall model that calculates a daily severity value using two action thresholds (DSV50 and DSV80); and a temperature-leaf-wetness model that calculates a daily value of infection probability using two action thresholds (DVIP6 and DVIP9)

\begin{tabular}{|c|c|c|c|c|c|c|c|c|c|c|}
\hline \multirow[b]{2}{*}{ Treatment } & \multicolumn{3}{|c|}{ Control efficacy $(\%)^{\mathrm{w}}$} & \multicolumn{3}{|c|}{ Number of sprays ${ }^{x}$} & \multirow[b]{2}{*}{$E^{\mathbf{y}}$} & \multicolumn{3}{|c|}{ Yield response $(\mathrm{kg} / \mathrm{ha})^{\mathrm{z}}$} \\
\hline & $C$ & $C_{U L}$ & $\mathbf{C}_{L L}$ & $N S$ & $N S_{U L}$ & $N S_{L L}$ & & $Y$ & $Y_{L L}$ & $Y_{U L}$ \\
\hline CAL & $74.2 \mathrm{ab}$ & 81.5 & 64.0 & 4.1 & 6.0 & 3.0 & 9.2 & $1,057.3 \mathrm{~b}$ & 851.5 & $1,263.1$ \\
\hline DSV80 & $46.0 \mathrm{c}$ & 61.3 & 24.7 & 1.8 & 5.0 & 0.0 & 25.4 & $537.5 \mathrm{c}$ & 331.6 & 743.3 \\
\hline DSV50 & $68.6 \mathrm{~b}$ & 77.5 & 56.2 & 3.4 & 5.0 & 0.0 & 21.8 & $975.3 \mathrm{~b}$ & 769.5 & $1,181.1$ \\
\hline DVIP6 & $82.7 \mathrm{a}$ & 87.6 & 75.9 & 4.7 & 6.0 & 2.0 & 7.1 & $1,261.4 \mathrm{a}$ & $1,050.1$ & $1,472.7$ \\
\hline DVIP9 & $75.7 \mathrm{ab}$ & 82.6 & 66.1 & 4.1 & 6.0 & 2.0 & 9.8 & $1,128.8 \mathrm{~b}$ & 917.5 & $1,340.1$ \\
\hline
\end{tabular}

${ }^{\mathrm{w}}$ Means of control $(C)$ and their respective upper $(U L)$ and lower $(L L)$ levels of $95 \%$ confidence interval (CI) obtained from back-transforming log-transformed means of the treatments, which were estimated by a mixed model for a set of 21 field experiments.

x Mean number of sprays $(N S)$ and their respective $U L$ and $L L$ of $95 \%$ CI estimated by a mixed-model analysis of 29 field experiments.

y Fungicide use efficiency calculated as the mean control efficacy divided by the mean number of sprays.

z Means of yield response $(Y)$ and their respective $U L$ and $L L$ of $95 \% \mathrm{CI}$ estimated by a mixed-model analysis of 29 field experiments. 
than in the untreated check), with only six cases of negative $D$ values (Fig. 4A). Whenever the costs of the treatments were taken into account, the yield response to break even shifted slightly toward negative values but remained positive for most treatments (Fig. 4B). In general, the probability of loss (Ploss), which is equivalent to the risk of not offsetting the costs of fungicide applications, was mostly below 0.5 across 145 scenarios. The Ploss exceeded 0.5 in approximately $20 \%$ of the scenarios and exceeded 0.7 in only $9.7 \%$ of the scenarios (Fig. 4C). The mean Ploss was similar $(P=$ 0.273 ) among the treatments, with the upper level of the estimated 95\% CI not reaching 0.5 Ploss, including the least effective system (DSV80), which consistently saved more sprays (Fig. 4D).

\section{Discussion}

Over more than 15 years seeking to mitigate and prevent SBR outbreaks in Brazil, several lessons have been learned with regard to disease control. Fungicides remain an indispensable tool in a soybean disease management program, and calendar-timed applications predominate, regardless of the season or region. However, alternative strategies for timing fungicide applications have received little attention in field research (Mueller et al. 2009). Most studies have focused on comparing the efficacy of fungicides applied on a fixed-interval basis and optimizing the interval between sprays based on the fungicide's residual period (Dalla Lana et al. 2018; Scherm et al. 2009).

Our study is the first comprehensive multilocation and multiseason evaluation of weather-based warning systems as an alternative to calendar-based sprays in SBR management. It is well known that increasing the number of sprays of an effective fungicide improves control up to a point (Dalla Lana et al. 2015). However, the present research explored whether accounting for weather conditions in determining spray timing can result in more cost-effective SBR management. In general, our results affirmed this hypothesis, given that the risk of not offsetting the costs of fungicide sprays was the same among all systems, on average. There were instances of fungicide applications not being economical, regardless of the spray timing system - a situation that is not implausible in Brazil given the wide variability in weather across regions and years that lead to varying
A
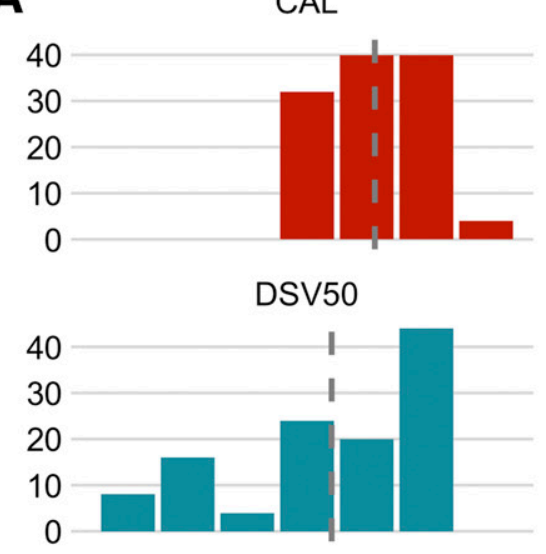

DSV80
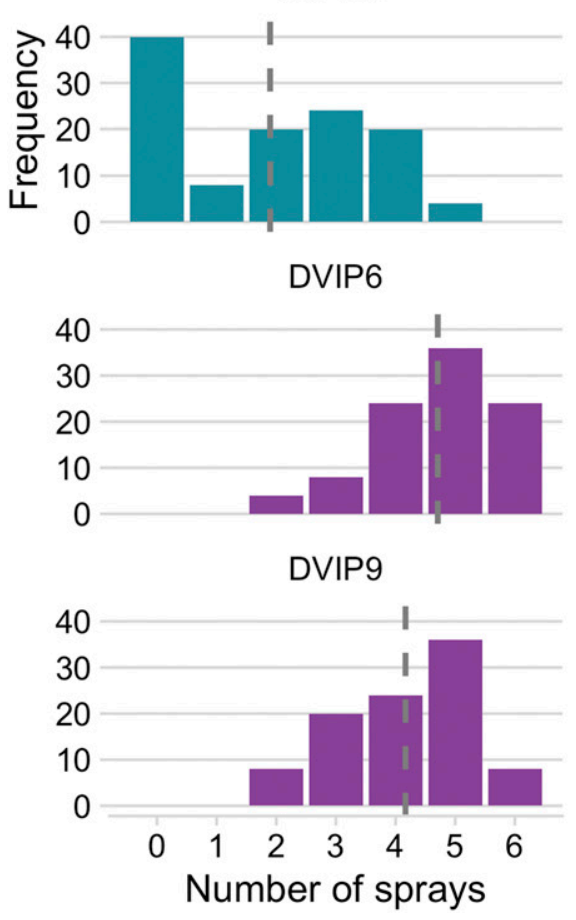

B

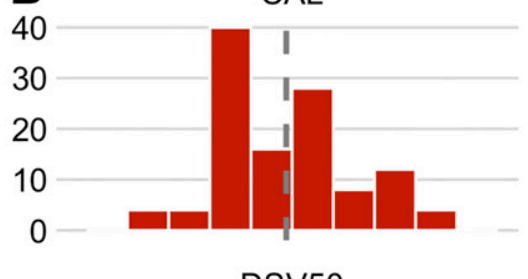

DSV50

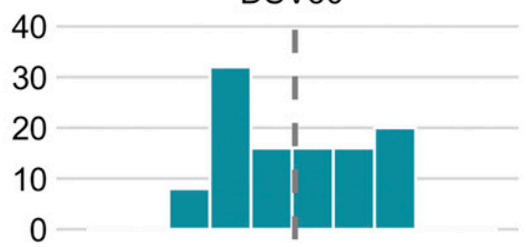

DSV80

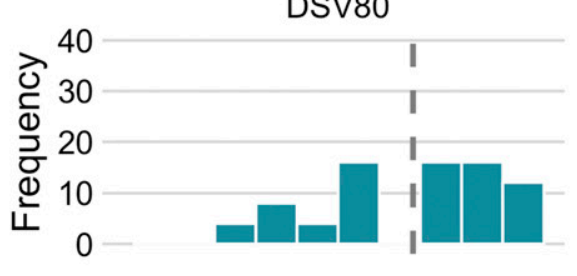

DVIP6

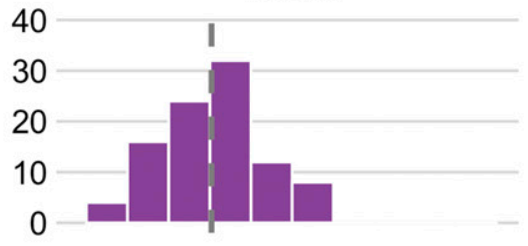

DVIP9

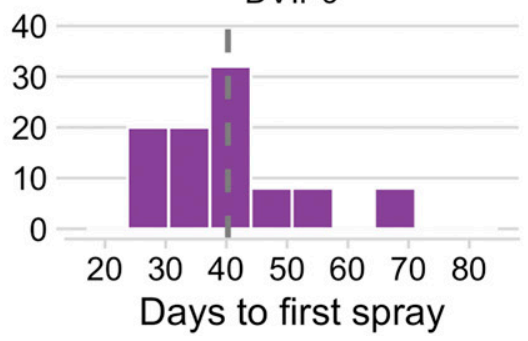

C

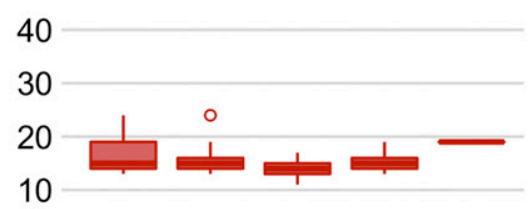

DSV50

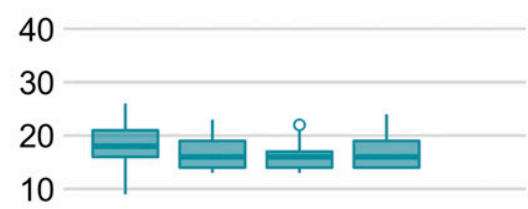

DSV80

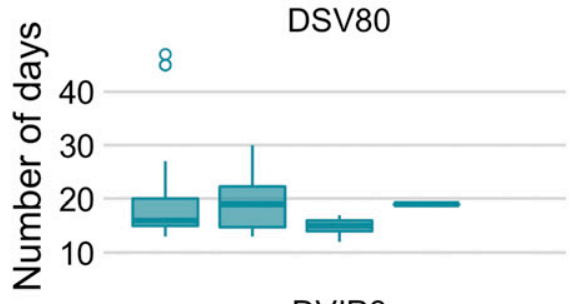

DVIP6

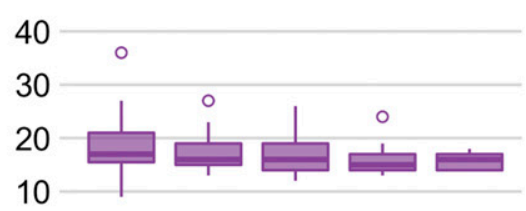

DVIP9

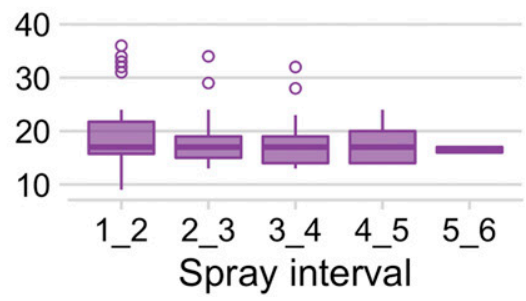

Fig. 3. A, Distribution of the number of sprays, B, number of days to first spray from planting date, and C, number of days between a pair of sprays (sequence interval) conditioned to five systems that based decision on the time of fungicide sprays: one is calendarized (CAL), and four are weather-based warning systems, each using two thresholds, that use rain (DSVs) or the interaction of leaf wetness duration and temperature (DVIPs). Data were available for 29 replicated field trial experiments conducted at six Brazilian locations in 2013, 2015 , and 2016. 
severity in the check treatment (Dalla Lana et al. 2015). Conducting numerous field trials across multiple seasons, locations, and sowing dates allowed us to evaluate decision criteria for timing fungicide sprays over a broad range of plausible scenarios (inoculum and disease pressures).

Given that profitability was similar among the systems, calendarbased fungicide spray timing offered advantages for soybean farmers aiming for convenience and zero investment in weather monitoring and warning systems. In contrast, threshold-based spray timing systems required disease scouting, weather monitoring, system management, and decision-making based on data interpretation. The total number of seasonal sprays in field crops, such as soybean, wheat, rice, and corn, is relatively lower than those required by high-value crops (e.g., tomato, apple, and grapes), which may justify the use of the calendar-based sprays in field crops, especially for defending against devastating diseases. SBR may lead to serious losses (Dalla Lana et al. 2015), but epidemics are largely weather-dependent (Del Ponte et al. 2006b). Saving one spray per season on average, as we observed for the relatively conservative warning system with the DSV50 threshold, resulted in SBR control as effective as calendar-based timing and represented a 20 to $30 \%$ reduction in the number of sprays. This is a considerable savings given the size of soybean acreage in Brazil (roughly 36 million hectares). It is also reasonable to expect that reducing spray frequency could reduce the risk of fungicide resistance (Godoy et al. 2017; Schmitz et al. 2014; Simões et al. 2018). Prevalence of calendar-timed spraying in Brazil, in conjunction with lack of rotation of fungicide classes, is likely to be contributing to the selection for resistance to fungicides in the pathogen population. The possibility that this urgent problem can be managed by reducing the number of unnecessary sprays using a weather-based DWS has been shown for other diseases of fruit and vegetable crops around the world (Abuley and Nielsen 2017; Gleason et al. 1995; Pavan et al. 2011; Rosli et al. 2017).

We evaluated a relatively simple rainfall-based system that eliminates the need for expensive equipment for onsite weather monitoring. The performance of the two rain-based systems, even with fewer sprays, showed it to be cost-effective compared with the two LWD-T systems. The more conservative LWD-T-based threshold led to even more spray advisories than the calendar-timed system, but it also showed larger variability in the between-spray interval than the rainfall-based DWSs, likely reflecting environmental variability in temperature and moisture. However, the greater number of sprays triggered by the LWD-T systems was likely due to the first spray being warned at $\sim 40$ days after sowing in the LWD-T systems, on average, compared with 51 and 63 days for the more and less conservative rain-based systems, respectively. This difference may be due to contrasting criteria for triggering the first spray or intrinsic differences in the weather input parameters. The rainfall model lacks any temperature variable, because it was not found to be critical in the development of epidemics in Brazil during the summer across the country (Del Ponte et al. 2006b). Rainfall is an important, but not the only, source of leaf wetness (Gleason et al. 2008). During nonrainy days, nighttime dew is an important source of canopy moisture and can be prolonged sufficiently to add up infection probability
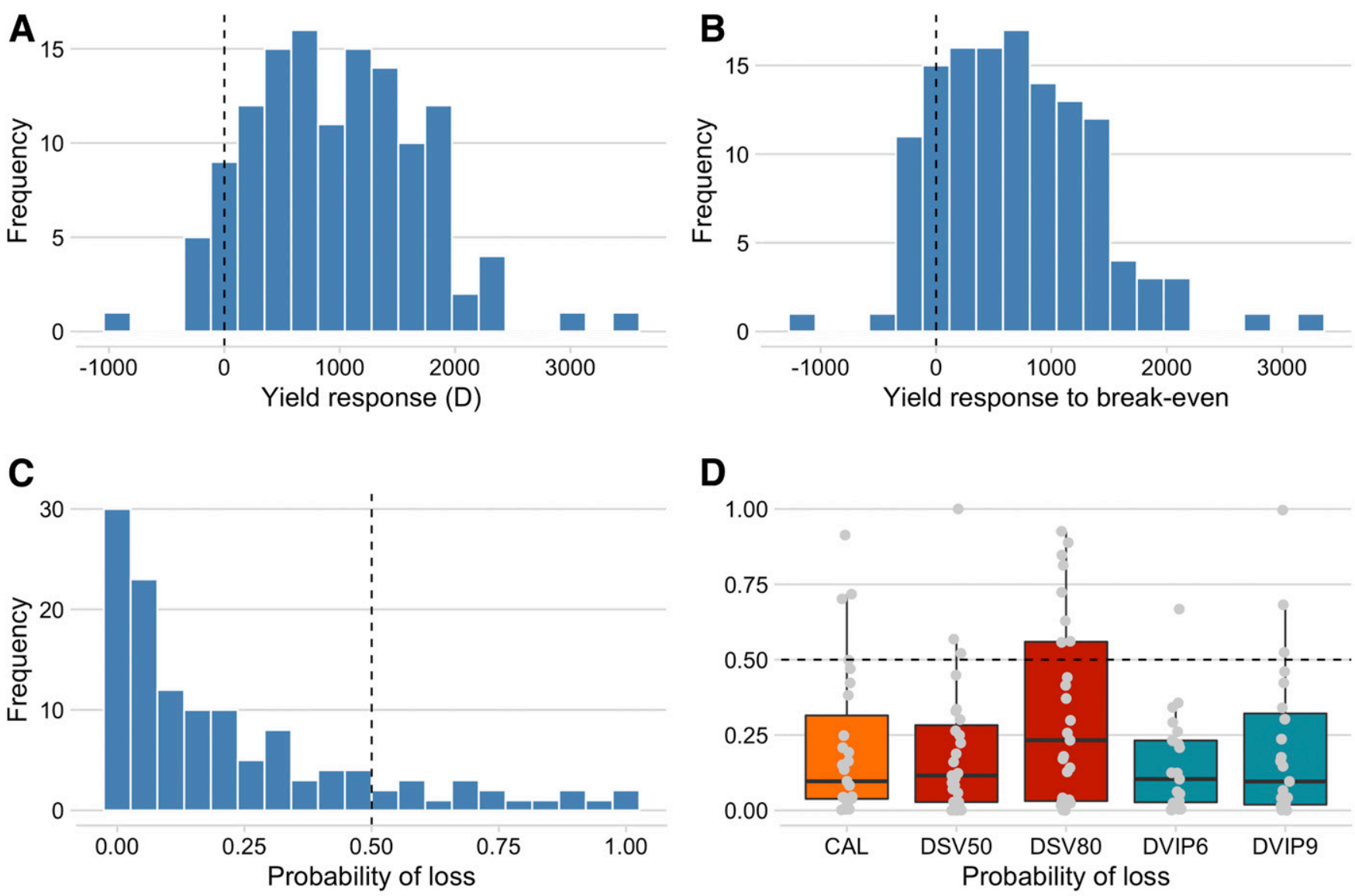

D

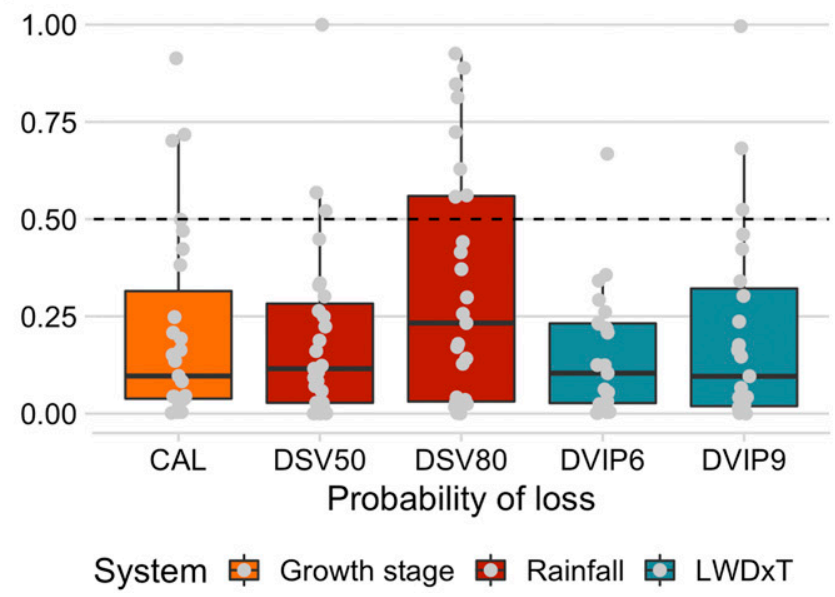

Fig. 4. Distribution of yield responses (A), yield responses to break-even on the fungicide costs (B), the probability of loss (C), or the risk of not recovering on the costs of fungicide sprays across all five systems (A to C) or conditioned to each system (D) to base the decision on the timing of fungicide sprays: one is calendarized (CAL), and four are weatherbased warning systems, each using two thresholds, that use rain (DSVs) or the interaction of leaf wetness duration and temperature (DVIPs). The dashed line in C and D represents the 0.5 probability level. Note that median risk is below the 0.5 threshold regardless of the system. Data were available for 29 replicated field trial experiments conducted at six Brazilian locations in 2013, 2015, and 2016. 
values, depending on how sensitive the warning system is to small differences in hourly estimates (Batzer et al. 2008).

Although early season weather may be favorable for infection, according to infection models, inoculum can be insufficient, thus resulting in false positives. More studies would be needed to understand the source of errors and further adjustments of LWD-T models to reduce sprays when they are not needed. However, the broad use of LWD in warning systems has been questioned, and simpler surrogates have been suggested such as relative humidity or rainfall (Rowlandson et al. 2015). In fact, LWD is not measured in most automatic weather stations, and leaf wetness sensors add to the overall cost and require calibration and maintenance (Sentelhas et al. 2004). The estimation of LWD may be problematic due to the problems in relative humidity sensor calibration, when opting to estimate LWD by the number of hours with relative humidity above a given threshold (Sentelhas et al. 2008), or the absence of a net radiation sensor in the weather stations when aiming to estimate LWD by the Penman-Monteith approach (Sentelhas and Gillespie 2008).

Our results with the rainfall-based systems are similar to those from a 3-year study conducted in the United States for SBR (Kelly et al. 2015). There, a simple rainfall-based "if-then" rule was derived: if cumulative rainfall for at least five rain events during the past 30 days was $\geq 130 \mathrm{~mm}$, then a spray was advised. The system was compared with an LWD-T system (if three consecutive days of $10 \mathrm{~h}$ or more of LWD and nighttime temperatures between 20 to $25^{\circ} \mathrm{C}$, then spray) and a two-spray calendar system. The rainbased rule reduced one to two sprays compared with the calendar and LWD-T system, with no reduction in yield. At conditions more favorable for the disease, compared with the calendar and LWD-T system, the rainfall-based model warned fewer sprays and yield was slightly reduced, but the economics were not calculated.

Earlier adaptation of the original rainfall-based model (Del Ponte et al. 2006b), different from what was proposed here, was used to (i) warn fungicide spray in a low-risk area in the south of Brazil where epidemics are more sporadic, which resulted in effective control with fewer sprays (Nunes et al. 2018) and (ii) produce large-scale risk maps of the main soybean regions in Brazil depicting the suitability for SBR epidemics during the season using gridded data of both past rainfall estimates and the rainfall forecast up to 15 days (Del Ponte and Dalla Lana 2012). At the field level, warnings could include rainfall forecasts, which are critical for operational decision making because a spray may be on hold if rain is very likely in the next day. This topic could be explored in future research, together with other factors that were not taken into account in our study, such as differences in soybean maturity groups, host resistance, and more complex fungicide programs that involve different systemic fungicides combined with the use of multisite and protectant fungicides, which have been used as an antiresistance strategy (Godoy et al. 2016; Zuntini et al. 2019).

In this study, only two thresholds (for the first spray) were tested for the rain-based model, and the results were quite distinct, suggesting that intermediate levels (DSV60 or DSV70) may be appropriate and worth testing. Finally, the season-decreasing values of action thresholds for each successive spray was defined based on the assumption that the risk increases after the first spray, which should be confirmed in future experiments comparing season-fixed thresholds. An early-season risk prediction of epidemics, such as one using oceanic index information such as El Nino Southern Oscillation (Del Ponte et al. 2011), combined with the information on the presence of the disease in the region, could be useful to map regions where more or less conservative thresholds should be employed for the first and subsequent sprays.

\section{Acknowledgments}

Thanks to Dr. Luis M. Schiebelbein, João V. de Mattos, Jessica J. Jaguela, and Bruno Marcantes for the support in Ponta Grossa, PR, field trials and to Mato Grosso Foundation for employee and technical support during field experiments in Campo Verde and Pedra Preta.

\section{Literature Cited}

Abuley, I. K., and Nielsen, B. J. 2017. Evaluation of models to control potato early blight (Alternaria solani) in Denmark. Crop Prot. 102:118-128.

Alvares, C. A., Stape, J. L., Sentelhas, P. C., de Moraes Gonçalves, J. L., and Sparovek, G. 2013. Köppen's climate classification map for Brazil. Meteorol. Z. (Berl.) 22:711-728

Bates, D., Mächler, M., Bolker, B. M., and Walker, S. C. 2015. Fitting linear mixed-effects models using lme4. J. Stat. Softw. 67:1-48.

Batzer, J. C., Gleason, M. L., Taylor, S. E., Koehler, K. J., and Monteiro, J. E. B. A. 2008. Spatial heterogeneity of leaf wetness duration in apple trees and its influence on performance of a warning system for Sooty Blotch and Flyspeck. Plant Dis. 92:164-170.

Dalla Lana, F., Paul, P. A., Godoy, C. V., Utiamada, C. M., Da Silva, L. H. C. P., Siqueri, F. V., Forcelini, C. A., Jaccoud-Filho, D. S., Miguel-Wruck, D. S., Borges, E. P., Juliatti, F. C., Campos, H. D., Nunes, J., Jr., Carneiro, L. C., Canteri, M. G., Ito, M. F., Meyer, M. C., Martins, M. C., Balardin, R. S., Furlan, S. H., Carlin, V. J., and Del Ponte, E. M. 2018. Meta-analytic modeling of the decline in performance of fungicides for managing soybean rust after a decade of use in Brazil. Plant Dis. 102:807-817.

Dalla Lana, F., Ziegelmann, P. K., de Maia, A. H. N., Godoy, C. V., and Del Ponte, E. M. 2015. Meta-analysis of the relationship between crop yield and soybean rust severity. Phytopathology 105:307-315.

Del Ponte, E. M., and Dalla Lana, F. 2012. Avaliação de risco de doenças de plantas: Conceitos e aplicações para decisões táticas e estratégicas no manejo. Pages 126-160 in: Avanços na otimização do uso de defensivos agrícolas no manejo fitossanitário. Núcleo de Estudos em Fitopatologia, ed. Suprema Gráfica e Editora, Lavras, Brazil.

Del Ponte, E. M., de Maia, A. H. N., dos Santos, T. V., Martins, E. J., and Baethgen, W. E. 2011. Early-season warning of soybean rust regional epidemics using El Niño Southern/Oscillation information. Int. J. Biometeorol. 55:575-583.

Del Ponte, E. M., and Esker, P. D. 2008. Meteorological factors and Asian soybean rust epidemic - A systems approach and implications for risk assessment. Sci. Agric. 65:88-97.

Del Ponte, E. M., Godoy, C. V., Canteri, M. G., Reis, E. M., and Yang, X. B. 2006a. Models and applications for risk assessment and prediction of Asian soybean rust epidemics. Fitopatol. Bras. 31:533-544.

Del Ponte, E. M., Godoy, C. V., Li, X., and Yang, X. B. 2006b. Predicting severity of Asian soybean rust epidemics with empirical rainfall models. Phytopathology 96:797-803.

Fehr, W. R., and Caviness, C. E. 1977. Stages of Soybean Development. Special Report 80. Iowa State University Cooperative Extension Service, Ames, IA.

Gandrud, C. 2016. Reproducible Research with R and R studio. Chapman and Hall/CRC, Boca Raton, FL.

Gent, D. H., Mahaffee, W. F., McRoberts, N., and Pfender, W. F. 2013. The use and role of predictive systems in disease management. Annu. Rev. Phytopathol. 51:267-289.

Gentleman, R., and Temple Lang, D. 2007. Statistical analyses and reproducible research. J. Comput. Graph. Stat. 16:1-23.

Gleason, M. L., Duttweiler, K. B., Batzer, J. C., Taylor, S. E., Sentelhas, P. C., Monteiro, J. E. B. A., et al. 2008. Obtaining weather data for input to crop disease-warning systems: Leaf wetness duration as a case study. Sci. Agric. 65:76-87.

Gleason, M. L., MacNab, A. A., Pitblado, R. E., Ricker, M. D., East, D. A., and Latin, R. X. 1995. Disease-warning systems for processing tomatoes in eastern North America: Are we there yet? Plant Dis. 79:113-121.

Godoy, C. V. 2011. Risk and management of fungicide resistance in the Asian soybean rust fungus Phakopsora pachyrhizi. Pages 87-95 in: Fungicide Resistance in Crop Protection: Risk and Management. T. S. Thind, ed. CABI, London, U.K.

Godoy, C. V., Koga, L. J., and Canteri, M. G. 2006. Diagrammatic scale for assessment of soybean rust severity. Fitopatol. Bras. 31:63-68.

Godoy, C. V., Seixas, C. D. S., Soares, R. M., Marcelino-Guimarães, F. C., Meyer, M. C., and Costamilan, L. M. 2016. Asian soybean rust in Brazil: Past, present, and future. Pesqui. Agropecu. Bras. 51:407-421.

Godoy, C. V., Utiamada, C. M., Meyer, M. C., Campos, H. D., Lopes, I., De, O. N. Forcelini, C. A., Pimenta, C. B., Jaccoud Filho, D. S., Moreira, E. N., Andrade Junior, E. R. de, Borges, E. P., Siqueri, F. V., Juliatti, F. C., Favero, F., Araujo Junior, I. P., Nunes Junior, J., Silva, L. H. C. P. da, Sato, L. N., Belufi, L. M. de R., Goussain, M., Volf, M. R., Debortoli, M. P., Martins, M. C., Balardin, R. S., Furlan, S. H., Madalosso, T., Carlin, V. J., and Venancio, W. S. 2017. Eficiência de fungicidas multissítios e produto biológico no controle da ferrugem-asiática da soja, Phakopsora pachyrhizi, na safra 2016/ 17: Resultados sumarizados dos ensaios cooperativos. Londrina, Brazil. https://www.infoteca.cnptia.embrapa.br/infoteca/handle/doc/1073218 [Accessed November 2, 2019].

Hartman, G. L., Rupe, J. C., Sikora, E. J., Domier, L. L., Davis, J. A., and Steffey, K. L., eds. 2016. Compendium of Soybean Diseases and Pests, 5th Ed. American Phytopathological Society, St. Paul, MN.

Hirano, M., Hikishima, M., da Silva, A. J., Xavier, S. A., and Canteri, M. G. 2010 Validação de escala diagramática para estimativa de desfolha provocada pela ferrugem asiática em soja. Summa Phytopathol. 36:248-250.

Igarashi, W. T., França, J. A., Silva, M. A. A., Igarashi, S., and Saab, O. J. G. A. 2016. Application of prediction models of Asian soybean rust in two crop seasons, in Londrina, Pr. Semina: Ciên Agr. 37:2881-2890. 
Kelly, H. M., Wright, D. L., Dufault, N. S., and Marois, J. J. 2015. Decision models for fungicide applications for soybean rust. Plant Health Prog. 16: 80-83.

Machado, F. J., Santana, F. M., Lau, D., and Del Ponte, E. M. 2017. Quantitative review of the effects of triazole and benzimidazole fungicides on fusarium head blight and wheat yield in Brazil. Plant Dis. 101:1633-1641.

Magarey, R. D., Fowler, G. A., Borchert, D. M., Sutton, T. B., Colunga-Garcia, M., and Simpson, J. A. 2007. NAPPFAST: An internet system for the weather-based mapping of plant pathogens. Plant Dis. 91:336-345.

Magarey, R. D., and Isard, S. A. 2017. A troubleshooting guide for mechanistic plant pest forecast models. J. Integr. Pest Manag. 8:1-7.

Magarey, R. D., and Sutton, T. B. 2007. How to create and deploy infection models for plant pathogens. Pages 3-25 in: General Concepts in Integrated Pest and Disease Management. A. Ciancio and K. G. Mukerji, eds. Springer, Dordrecht, the Netherlands.

Marchetti, M. A., Melching, J. S., and Bromfield, K. R. 1976. The effects of temperature and dew period on germination and infection by uredospores of Phakopsora pachyrhizi. Phytopathology 66:461-463.

Megeto, G. A. S., Oliveira, S. R. D. M., Del Ponte, E. M., and Meira, C. A. A. 2014. Árvore de decisão para classificação de ocorrências de ferrugem asiáticaem lavouras comerciais com base em variáveis meteorológicas. Eng. Agric. 34:590-599.

Melching, J. S., Dowler, W. M., Koogle, D. L., and Royer, M. H. 1989. Effects of duration, frequency, and temperature of leaf wetness periods on soybean rust. Plant Dis. 73:117-122.

Minchio, C. A., Canteri, M. G., Fantin, L. H., and de Aguiar e Silva, M. A. 2016. Epidemias de ferrugem asiática no Rio Grande do Sul explicadas pelo fenômeno ENOS e pela incidência da doença na entressafra. Summa Phytopathol. 42:321-326.

Mueller, T. A., Miles, M. R., Morel, W., Marois, J. J., Wright, D. L., Kemerait, R. C., Levy, C., and Hartman, G. L. 2009. Effect of fungicide and timing of application on soybean rust severity and yield. Plant Dis. 93:243-248.

Nunes, C. D. M., da Silva Martins, J. F., and Del Ponte, E. M. 2018. Pages 1-13 in: Validação de modelo de previsão de ocorrência da ferrugem asiática da soja com base em precipitação pluviométrica. Embrapa Clima Temperado. Circular Técnica 199. Embrapa, Brasilia, Brazil.

Paul, P. A., Lipps, P. E., Hershman, D. E., McMullen, M. P., Draper, M. A., and Madden, L. V. 2008. Efficacy of triazole-based fungicides for Fusarium head blight and deoxynivalenol control in wheat: A multivariate meta-analysis. Phytopathology 98:999-1011.

Paul, P. A., McMullen, M. P., Hershman, D. E., and Madden, L. V. 2010. Metaanalysis of the effects of triazole-based fungicides on wheat yield and test weight as influenced by Fusarium head blight intensity. Phytopathology 100: 160-171.

Pavan, W., Fraisse, C. W., and Peres, N. A. 2011. Development of a web-based disease forecasting system for strawberries. Comput. Electron. Agric. 75:169-175.

Reis, E. M., Sartori, A. F., and Câmara, R. K. 2004. Modelo climático para a previsão da ferrugem da soja. Summa Phytopathol. 30:290-292.
Rosli, H., Mayfield, D. A., Batzer, J. C., Dixon, P. M., Zhang, W., and Gleason, M. L. 2017. Evaluating the performance of a relative humidity-based warning system for sooty blotch and flyspeck in Iowa. Plant Dis. 101:1721-1728.

Rossi, V., Giosuè, S., and Caffi, T. 2010. Modelling plant diseases for decision making in crop protection. Pages 241-258 in: Precision Crop Protection-The Challenge and Use of Heterogeneity. E. C. Oerke, R. Gerhards, G. Menz, and R. Sikora, eds. Springer, Dordrecht, the Netherlands.

Rowlandson, T., Gleason, M., Sentelhas, P., Gillespie, T., Thomas, C., and Hornbuckle, B. 2015. Reconsidering leaf wetness duration determination for plant disease management. Plant Dis. 99:310-319.

Scherm, H., Christiano, R. S. C., Esker, P. D., Del Ponte, E. M., and Godoy, C. V. 2009. Quantitative review of fungicide efficacy trials for managing soybean rust in Brazil. Crop Prot. 28:774-782.

Schmitz, H. K., Medeiros, C. A., Craig, I. R., and Stammler, G. 2014. Sensitivity of Phakopsora pachyrhizi towards quinone-outside-inhibitors and demethylationinhibitors, and corresponding resistance mechanisms. Pest Manag. Sci. 70: 378-388.

Sentelhas, P. C., Dalla Marta, A., Orlandini, S., Santos, E. A., Gillespie, T. J., and Gleason, M. L. 2008. Suitability of relative humidity as an estimator of leaf wetness duration. Agric. For. Meteorol. 148:392-400.

Sentelhas, P. C., and Gillespie, T. J. 2008. Estimating hourly net radiation for leaf wetness duration using the Penman-Monteith equation. Theor. Appl. Climatol. 91:205-215.

Sentelhas, P. C., Gillespie, T. J., Gleason, M. L., Monteiro, J. E. B. A., and Helland, S. T. 2004. Operational exposure of leaf wetness sensors. Agric. For. Meteorol. 126:59-72

Shtienberg, D. 2000. Modelling: The basis for rational disease management. Crop Prot. 19:747-752.

Simões, K., Hawlik, A., Rehfus, A., Gava, F., and Stammler, G. 2018. Firs detection of a SDH variant with reduced SDHI sensitivity in Phakopsora pachyrhizi. J. Plant Dis. Prot. 125:21-26.

Small, I. M., Joseph, P., and Fry, W. E. 2015. Evaluation of the BlightPro decision support system for management of potato late blight using computer simulation and field validation. Phytopathology 105:1545-1554.

Tao, Z., Malvick, D., Claybrooke, R., Floyd, C., Bernacchi, C. J., Spoden, G., Kurle, J., Gay, D., Bowersox, V., and Krupa, S. 2009. Predicting the risk of soybean rust in Minnesota based on an integrated atmospheric model. Int. J. Biometeorol. 53:509-521.

Wickham, H., Averick, M., Bryan, J., Chang, W., McGowan, L. D., François, R., Grolemund, G., Hayes, A., Henry, L., Hester, J., Kuhn, M., Pedersen, T. L. Miller, E., Bache, S. M., Müller, K., Ooms, J., Robinson, D., Seidel, D. P., Spinu, V., Takahashi, K., Vaughan, D., Wilke, C., Woo, K., and Yutani, H. 2019. Welcome to the Tidyverse. J. Open Source Softw. 4:1686.

Xie, Y., Allaire, J. J., and Grolemund, G. 2018. R Markdown: The Definitive Guide. Chapman and Hall/CRC, Boca Raton, FL.

Zuntini, B., Alvarez, R., Theodoro, G. de F., and Zuffo, A. M. 2019. Effect of adding fungicide to mixtures of triazoles and strobilurins in the control of downy mildew and Asian soybean rust. Pesqui. Agropecu. Trop. 49:e53688. 